\title{
Rekonsiliasi Konflik Antarperguruan Silat di Madiun (Studi Historis Sosiologis)
}

\author{
Soebijantoro \\ Abraham Nurcahyo \\ Yudi Hartono *)
}

\begin{abstract}
Abstrak
Penelitian ini bertujuan untuk: 1) Mengungkap akar penyebab konflik antarperguruan silat di Madiun; 2) Mengidentifikasi momentum-momentum dan tempat yang sering menjadi arena konflik; 3) Mengidentifikasi potensipotensi integrasi yang dapat diberdayakan sebagai media penyelesaian konflik; 4) Merumuskan kerangka teoretik rekonsiliasi yang dapat diterapkan untuk menangani konflik antarperguruan silat di Madiun. Jenis penelitian deskriptif kualitatif. Data diperoleh dengan wawancara mendalam, observasi langsung, mencatat dokumen dan arsip. Data diperoleh melalui wawancara mendalam, observasi langsung, mencatat dokumen dan arsip. Validasi data dilakukan melalui teknik triangulasi sumber, teknik, dan peneliti. Analisis data dilakukan dengan teknik analisis interaktif.

Hasil penelitian menunjukkan bahwa konflik melibatkan faktor-faktor historis yang berdampak pada situasi sosiologis. Faktor historis berakar dari perbedaan pendapat guru-murid generasi awal dalam pengembangan Perguruan Setia Hati. Saat itu konflik masih pada fase latensi dimana perbedaan masih dapat diterima. Konflik bereskalasi pasca Peristiwa G30S ketika terjadi bentrok antarpendekar SH Terate dengan SH Winongo, meskipun keduanya bukanlah partisan dalam peristiwa tersebut. Hubungan mulai memburuk dan stereotip negatif mulai berkembang. Konflik semakin meluas sejak tahun 1990-an ketika jumlah anggota baru keduanya semakin meningkat. Pelanggaran etika perguruan mulai merebak karena tidak adanya sanksi organisatoris. Kekerasan mudah meletus dan melibatkan massa pendukung yang banyak. Konflik memasuki fase terjebak. Berbagai momentum yang sesungguhnya memiliki spirit yang sama seperti Suran Agung, Halal bihalal, dan pengesahan anggota baru justru menjadi arena konflik.

Karakteristik konflik menentukan cara-cara penyelesaiannya. Tindakan pengamanan untuk menghentikan kekerasan cukup efektif dilakukan aparat. Namun demikian, suasana sosiopsikologis di tingkat bawah belum banyak berubah. Rekonsiliasi dengan pendekatan kultural menjadi pilihan. Arenaarena integrasi seperti Festival Pencak Seni Tradisi diberdayakan sebagai media rekonsiliasi dengan pendekatan kultural. Rekonsiliasi kultural merupakan upaya rekonsiliasi dengan memberdayakan unsur-unsur budaya
\end{abstract}

* Soebijantoro, Abraham Nurcahyo, Yudi Hartono adalah Dosen Pendidikan Sejarah IKIP PGRI MADIUN 
dan sosial yang dapat menjadi perekat bersama untuk menciptakan suasana dialogis dan harmonis melalui cara-cara proeksistensi yang terjelmakan ke dalam tindakan dan aksi-aksi nyata dalam berbagai peristiwa kehidupan.

\section{Kata Kunci: Rekonsiliasi, konflik, perguruan silat}

\section{Pendahuluan}

Konflik sosial di Madiun yang melibatkan dua perguruan silat, yaitu antara Persaudaraan Setia Hati Terate dengan Persaudaraan Setia Hati Winongo Tunas Muda merupakan fenomena yang banyak mendapat perhatian masyarakat Madiun dan sekitarnya, bahkan telah menjadi bahan pemberitaan nasional. Konflik tersebut menimbulkan ketidaknyaman dalam kehidupan masyarakat karena telah mengarah pada kekerasan massal. Bagi kedua perguruan menjadi ironis, karena mereka telah banyak berkontribusi bagi kemajuan pencak silat di tingkat regional dan nasional, namun di tingkat lokal mereka menghadapi persoalan diantara mereka sendiri.

Kehidupan sosial selalu mengandung dua potensi yang saling bertolak belakang, yaitu potensi konflik dan integrasi. Kedua potensi tersebut menyatu dalam kehidupan masyarakat dan sewaktu-waktu dapat muncul secara bergantian. Potensi konflik akan muncul lebih kuat apabila diantara anggota masyarakat lebih mengutamakan kepentingan individu ataupun kelompok sehingga terjadi persaingan tidak sehat yang pada akhirnya dapat memicu konflik. Potensi integrasi akan lebih dominan apabila diantara anggota masyarakat lebih mengutamakan kepentingan bersama yang dilandasi oleh nilai dan norma sosial sehingga akan tercipta suasana damai.

Konflik merupakan hal yang wajar dalam kehidupan sosial. Konflik merupakan bagian dari dinamika masyarakat yang dapat mendorong perubahan, namun konflik akan menjadi destruktif apabila mengarah pada kekerasan. Konflik akan bersifat negatif apabila terjadi berkepanjangan dan diwarnai dengan kekerasan yang pada akhirnya dapat merusak tatanan kehidupan dan merugikan masyarakat. Jika konflik telah tidak terelakkan, maka pilihannya adalah mengelolanya agar tidak berubah menjadi kekerasan. Jika konflik dibiarkan menjadi kekerasan, maka kerugian akan terjadi, termasuk kerugian harkat dan martabat manusia yang terlibat dan terkena dampak kekerasan itu.

Konflik berbeda dari kekerasan. Suatu ketegangan dan persengketaan disebut sebagai konflik jika masing-masing pihak masih bergerak di wilayah haknya. Jika telah terjadi pelanggaran wilayah hak, maka konflik telah berubah menjadi kekerasan. Manajemen konflik menjadi penting untuk mencegah berubahnya konflik menjadi kekerasan. Untuk itu diperlukan wawasan dan bekal mengenai cara-cara mengelola konflik yang kesemuanya menghindar-kan kekerasan.

Kemampuan mengelola konflik mencerminkan keadaban. Masyarakat damai bukanlah masyarakat yang hidup tanpa konflik, melainkan masyarakat yang konfliknya dapat dikelola sehingga menjadi kekuatan transformatif. Kualitas manusia dalam relasi antarsesamanya tidak diukur dari kemampuannya menghindari konflik, melainkan pada kemampuannya menyelesaikan konflik tanpa kekerasan berprinsip keadilan.

Tidak ada cara tunggal untuk menyelesaikan konflik. Konflik selalu khas ter- 
gantung permasalahan yang dipersengketakan, pihak-pihak yang terlibat, tindakan yang muncul, kepentingan dan kebutuhan yang hendak dicapai, dan opsi penyelesaiannya. Kekhasan itu juga dipengaruhi oleh budaya, nilai-nilai yang dianut, sistem sosial dan sistem hukum yang diterapkan, dan konteks lainnya. Oleh karena itu cara yang efektif di suatu masyarakat belum tentu efektif jika diterapkan pada masyarakat lainnya (Dian Nafi', 2005:2).

Dalam konteks konflik sosial yang terjadi antarperguruan silat di Madiun diperlukan upaya pengelolaan dan cara-cara penanganan yang relevan dengan karakteristik konfliknya sehingga dapat mencegah pihak-pihak berkonflik dari kekerasan. Disinilah urgensi penelitian ini untuk mengungkap akar penyebab, momentum-momentun ataupun tempat yang sering menjadi arena konflik, potensi-potensi integrasi yang dapat diberdayakan sebagai media penyelesaian konflik, dan kerangka teoretik rekonsiliasi yang dapat diterapkan untuk menangani konflik antarperguruan silat di Madiun..

\section{Tujuan dan manfaat penelitian}

Tujuan penelitian ini sebagai berikut.

1. Mengungkap akar penyebab konflik antarperguruan silat di Madiun.

2. Mengidentifikasi momentum-momentum dan tempat yang sering menjadi arena konflik.

3. Mengidentifikasi potensi-potensi integrasi yang dapat diberdayakan sebagai media penyelesaian konflik.

4. Merumuskan kerangka teoretik rekonsiliasi yang dapat diterapkan untuk menangani konflik antarperguruan silat di Madiun.
Hasil penelitian ini diharapkan dapat bermanfaat sebagai berikut.

1. Memberi sumbangan bagi perkembangan ilmu sosial dan ilmu sejarah, terutama sejarah sosial dan sejarah lokal.

2. Menjadi bahan masukan bagi Pemerintah Kabupaten dan Pemerintah Kota Madiun serta aparat keamanan dalam mengelola konflik antara $\mathrm{SH}$ Winongo dan SH Terate.

3. Menjadi bahan masukan bagi Pengurus SH Winongo dan SH Terate dalam mengelola konflik.

4. Menjadi acuan bagi penelitian selanjutnya yang terkait rekonsiliasi konflik.

\section{Tinjauan Pustaka}

\section{A. Perspektif Teoretik Tentang Konflik}

Istilah konflik secara etimologis berasal dari bahasa Latin "con" yang berarti bersama, dan "fligere" yang berarti benturan atau tabrakan. Dengan demikian konflik dalam kehidupan sosial berarti terjadinya benturan kepentingan, pendapat, harapan yang harus diwujudkan. Konflik sosial paling tidak melibatkan dua pihak atau lebih. Tiaptiap pihak dapat berupa perorangan, keluarga, kelompok kekerabatan, satu komunitas, maupun satu organisasi sosial pendukung ideologi tertentu, satu organisasi politik, suku bangsa ataupun satu pemeluk agama tertentu.

William Chang (2001) pernah mempertanyakan tentang dimensi konflik tersebut, apakah konflik yang terjadi di masyarakat hanya dilatarbelakangi oleh ketidakpuasan batin, kecemburuan, kebencian, masalah tanah, modal kapital maupun kekuasaan? Pertanyaan ini kemudian dijawab sendiri oleh Chang bahwa emosi sesaat pun ternyata dapat menimbulkan konflik sosial. Konflik-konflik yang tidak 
terhindarkan telah memecah belah, memutuskan tali persaudaraan, dan malah meniadakan hidup umat manusia. Konflik individual dan konflik sosial itu, antara lain ditimbulkan ketidakpuasan batin seseorang untuk menerima diri, berhadapan dengan orang atau pihak lain, kecemburuan, iri hati, benci, dan jiwa kontroversial. Konflik individual, jika tidak cepat diatasi, dapat mengundang konflik sosial.

Dimensi konflik pada hakekatnya adalah adanya perbedaan prinsip ataupun kepentingan yang terjadi dalam masyarakat. Fenomena ini kadangkala juga ditunggangi oleh agenda setting yang lebih besar dari struktur yang dominan yang berkuasa dibandingkan dengan hanya sekedar perbedaan persepsi yang ada di masyarakat. Agenda setting dari struktur yang dominan inilah yang sebenarnya memainkan peranan penting dalam terjadinya konflik kepentingan di masyarakat.

Dalam kehidupan sosial, terdapat sebuah struktur yang erat hubungannya dengan sistem sosial yang ada, yaitu struktur sosial. Berbeda dengan sistem sosial yang menekankan pada sejumlah orang atau sekelompok orang dengan aktifitasnya yang mempunyai hubungan relatif tetap dan konstan, struktur sosial berkaitan dengan pola hak dan kewajiban para pelaku dalam interaksi sosialnya yang terwujud dalam hubungan sosial yang relatif stabil dalam jangka waktu tertentu.

Hak dan status para pelaku dihubungkan dengan status dan peranan masing-masing pelaku. Status dan peranan ini berdasar pada sistem penggolongan yang ada dalam masyarakat yang bersangutan, baik berupa ascribed status maupun achieved status. Status dan peranan tersebut pada umumnya hanya berlaku menurut masing-masing kesatuan sosial dan situasi interaksi sosial pada saat tertentu saja.
Pendapat lain dikemukakan oleh Peter M. Blau (1964) yang menyatakan bahwa struktur sosial adalah penyebaran secara kuantitatif warga komunitas di dalam berbagai posisi yang berbeda yang pada akhirnya mempengaruhi hubungan diantara mereka, termasuk juga di dalamnya hubungan konflik. Karateristik pokok dari struktur adalah adanya ketidaksamaan atau keberagaman antar bagian dan konsolidasi yang timbul dalam kehidupan bersama sehingga mempengaruhi derajat hubungan antar bagian tersebut yang berupa dominasi, eksploitasi, konflik, persaingan dan kerjasama.

Blau mengelompokkan basis parameter pembedaan struktur menjadi dua bagian, yaitu parameter nominal dan gradual. Parameter nominal membagi komunitas menjadi sub-sub bagian atas dasar batas yang cukup jelas, seperti, ras, agama, jenis kelamin, pekerjaan, afiliasi politik, tempat tinggal, bahasa, nasionalitas dan sebagainya. Kalau dicermati, pengelompokkan ini bersifat horizontal dan akan melahirkan berbagai golongan. Adapun parameter gradual membagi komunitas dalam kelompok sosial atas dasar peringkat status sosial yang nantinya akan menciptakan perbedaan kelas sosial seperti pendidikan, pendapatan, kekayaan, prestise, kekuasaan, kewibawaan, intelegensia dan sebagainya. Dengan kata lain, pengelompokkan ini bersifat vertikal dan akan menghasilkan lapisan dalam masyarakat.

Atas dasar struktur sosial yang dikatakan oleh Peter M. Blau di atas, maka dapat dikemukakan bahwa interaksi antarbagian dalam kehidupan bersama dapat terjadi antar kelompok, baik atas dasar parameter nominal maupun gradual; bahkan tidak hanya internal, tetapi juga secara eksternal. Interaksi antar bagian dalam kehidupan sosial tersebut, baik atas dasar parameter nominal maupun gradual 
dapat menimbulkan konflik antar individu anggota dari berbagai golongan dan lapisan.

Menurut sosiolog Relf Dahrendorf (dalam Leo Agustino (2006), pemahaman masalah konflik mencakup 2 (dua) makna, yaitu: (a) konflik merupakan akibat dan proses integrasi di dalam masyarakat yang tidak tuntas. Dalam konteks ini, konflik merupakan sebuah mencakup 2 (dua) makna, yaitu: (a) konflik merupakan akibat dan proses integrasi di dalam masyarakat yang tidak tuntas. Dalam konteks ini, konflik merupakan sebuah sympton (gejala penyakit) yang dapat merusak persatuan dan kesatuan masyarakat; dan (b) konflik merupakan proses alami dalam rangka sebuah proyek rekonstruksi sosial. Dalam hal ini konflik dapat dilihat secara fungsional sebagai suatu strategi untuk menghilangkan unsur-unsur disintegrasi dalam masyarakat yang tidak terintegrasi secara sempurna.

Dahrendorf mengemukakan bahwa konflik sosial yang terjadi dalam masyarakat mempunyai sumber struktural, yakni hubungan kekuasaan yang berlaku dalam struktur organisasi sosial. Dengan kata lain, konflik antar kelompok dapat dilihat dari sudut keabsahan hubungan kekuasaan yang ada atau dari struktur sosial setempat. Teori Dahrendorf ini menyatakan bahwa konflik sosial merupakan akibat dari terjadinya kegalauan masyarakat yang bersumber dari ketidakserasian esensi bermacam komponen kehidupan. Kebalikannya adalah teori kohesi dari Bronislaw Malinowski yang mengatakan bahwa keutuhan akan terjadi bila satu wilayah kehidupan dilandasi secara kuat oleh keuntungan timbal balik dibawah prinsip-rinsip legal.

Menurut Talcott Parson (1951), dalam setiap sistem sosial diperlukan persyaratan fungsional. Diantara persyaratan itu dijelaskan bahwa sistem sosial harus dapat menyesuaikan diri dengan lingkungannya dan dengan tuntutan trans- formasi pada setiap kondisi tindakan warga (adaptation). Selanjutnya, tindakan warga diarahkan untuk tujuan bersama (goal attainment). Persyaratan lainnya adalah bahwa dalam interaksi antar warga setidaknya harus ada suatu tingkatan solidaritas, agar struktur dan sistem sosial berfungsi (integration). Teori fungsionalisme dari Talcott Parson ini mengatakan bahwa tertib sosial ditentukan oleh adanya hubungan timbal balik antara sistem-sistem kebudayaan, sosial dan kepribadian dalam masyarakat.

Fungsi sosial tidak hanya berbicara mengenai peran, karena relasi fungsi tidak selalu saja terpadu, akan tetapi dalam relasi sosial tersebut bisa saja terdapat konflik di dalamnya, apalagi jika didalamnya banyak terdapat cukup banyak faksi. Dalam fungsi terdapat struktur, dan dalam fakta juga terdapat struktur dan fungsi yang saling berkait erat. Teori fungsi tidak dirancang dalam kaitannya dengan perubahan, sehingga keduanya agak sulit dihubungkan. Teori fungsi hanya terbatas menyangkut hubungan-hubungan yang bersifat serasi saja dan kurang memperhatikan hubunganhubungan yang bersifat konflik.

Struktur dan fungsi kaitannya dengan persoalan konflik bukanlah sesuatu yang sederhana. Struktur maupun fungsi, dalam setiap kehidupan sosial manusia pada hakikatnya tidak seragam, artinya dalam setiap setting kehidupan manusia mempunyai struktur dan fungsi yang berbeda satu sama lain. Pun halnya demikian dengan konflik, tidak selalu sama, terdapat konflik antar individu maupun antar masyarakat, konflik terbuka maupun tertutup. Akan tetapi satu hal yang perlu diperhatikan adalah, apapun bentuk ancaman kerawanan sosial maupun konflik yang terjadi pada suatu daerah, perlu sebuah analisa kritis dalam kedudukannya yang tidak begitu saja bisa dilepaskan dari 
struktur dan fungsi yang ada pada masyarakat tersebut. Dengan kata lain, konflik tidak bisa dilepaskan dari struktur sosial kehidupan masyarakat, karena konflik pada hakikatnya berfungsi sebagai terciptanya integrasi kehidupan sosial.

Integrasi sosial akan tercermin dalam institusi sosial, dan inilah kebutuhan dasar manusia, bahwa manusia membutuhkan pengorganisasian sosial untuk memenuhi kebutuhan sosialnya. Sebagai kelanjutannya, respon dari hal ini adalah terwujudnya kebudayaan yang termaktub dalam pembentukan institusi-institusi sosial. Dengan kata lain, kebudayaan sebagai respon basic need dapat diindikasikan sebagai instrumen untuk mencapai tujuan bersama masyarakat.

\section{B. Konflik dan Kekerasan}

Berbagai perspektif tentang konflik sosial di atas merupakan sudut pandang konflik sebagai fenomena wajar dalam kehidupan sosial. Konflik dalam konteks tersebut justru dapat menjadi potensi konstruktif yang dapat mendorong perubahan apabila dapat dikelola dengan baik. Namun demikian, konflik akan menjadi destruktif apabila telah mengarah pada kekerasan.

Kekerasan merupakan manifestasi jiwa dan hati yang galau. Orang yang melakukan kekerasan biasanya jiwanya merasa terancam, dikucilkan, dan terimpit oleh tekanan-tekanan yang terjadi di sekelilingnya. Oleh karenanya, kekerasan dianggap sebagai obat penawar yang bisa menyembuhkan kegalauannya tersebut. Padahal, kekerasan sebetulnya bukan penyelesaian masalah yang bersifat substansial dan jangka panjang, karena ia hanya bersifat artifisial dan bahkan dapat mendatangkan masalah lanjutan baru (Ahmad Fuad Fanani, 2003 ).

Helder Camara mengingatkan bahwa kekerasan di masyarakat bersifat akumulatif, artinya bahwa ada kekerasan yang mendahului. Kekerasan melahirkan kekerasan. Inilah spiral kekerasan yang tersusun tiga lapis. Pertama, kekerasan ketidakadilan akibat egoisme penguasa dan kelompok. Kedua, perjuangan keadilan lewat kekerasan. Ketiga, kekerasan dari tindakan represi pemerintah (dalam Toto Suparto, 2006). Dalam segala keadaan, kekerasan dan kecepatan dihargai lebih daripada penghormatan kepada aturan hukum. Penggunaan kekerasan sering dipandang sebagai salah satu model penyelesaian konflik di mana satu pihak atau kelompok melalui penggunaan alat-alat yang bersifat fisik, merugikan pihak atau kelompok lain dalam usaha penyelesaian konflik. Penggunaan kekerasan dianggap benar dengan argumen sebagai cara yang paling tepat dan satu-satunya yang masih tersisa. Namun demikian, cara ini bukan tanpa risiko, karena akan menimbulkan "spiral" kekerasan, yaitu dapat menimbulkan reaksi balik yang juga berwujud kekerasan (Achmad Ali, 2004).

Kekerasan merupakan kejahatan struktural yang paling berbahaya. Sementara itu, kekerasan yang paling sulit dibongkar adalah kekerasan psikologi yang dipakai dalam sistem politik. Sebagai alat, kekerasan psikologis ini sulit untuk dipisahkan dari kekerasan negara atau kekerasan yang terlembagakan. Meski awalnya sebagai ekses dan penyalah-gunaan, akan tetapi lebih dikaitkan dengan negasi terhadap martabat manusia yang dilembagakan, karena bukan sekadar sesuatu yang terjadi secara kebetulan atau sesaat saja, tetapi didukung oleh bangunan sosial dan politik (Haryatmoko, 2001). Dengan demikian, kejahatan struktural merupakan kejahatan moral dan hukum sebagai akibat dari kejahatan pribadi dan kejahatan kolektif 
yang menghasilkan struktur-struktur yang mengkondisikan tindakan baik individu maupun kolektif mengarah ke kejahatan.

\section{Tahapan Konflik dan Rekonsiliasi}

Konflik berkembang dari fase latensi, eskalasi, terjebak, perbaikan, dan transformasi. Pada fase latensi perbedaan yang ada dapat diterima. Pada fase eskalasi komunikasi terhambat, kelompok-kelompok mengeras, dan sumber-sumber dikerahkan. Pada fase terjebak komunikasi putus, kekerasan meletus, terjadi segregasi sosial, pemenuhan kebutuhan dasar terhambat dan krisis terjadi. Pada fase perbaikan kejenuhan terhadap kekerasan dan kerinduan akan masa damai. Dan pada fase transformasi perdamaian dinilai mem- berikan penyelesaian masalah yang tidak cukup memuaskan.

Tindakan rekonsiliatif tergantung fase konfliknya. Jika fase konfliknya masih laten, maka perlu dilakukan peace building dengan kegiatan-kegiatan pencegahan konflik. Di dalamnya setiap usaha menciptakan keadilan sosial menjadi sangat penting. Saat konflik memanas (bereskalasi), maka pencegahan konflik harus ditingkatkan dengan berbagai kegiatan lintas komunitas. Jika konflik sudah mencapai puncaknya, terjebak atau entrapment, maka program humanitarian bisa dipergunakan untuk mengawali upaya-upaya rekonsiliasi seiring dengan tindakan keamanan untuk penghentian kekerasan.

\section{Gambar 1: Intensitas Konflik}

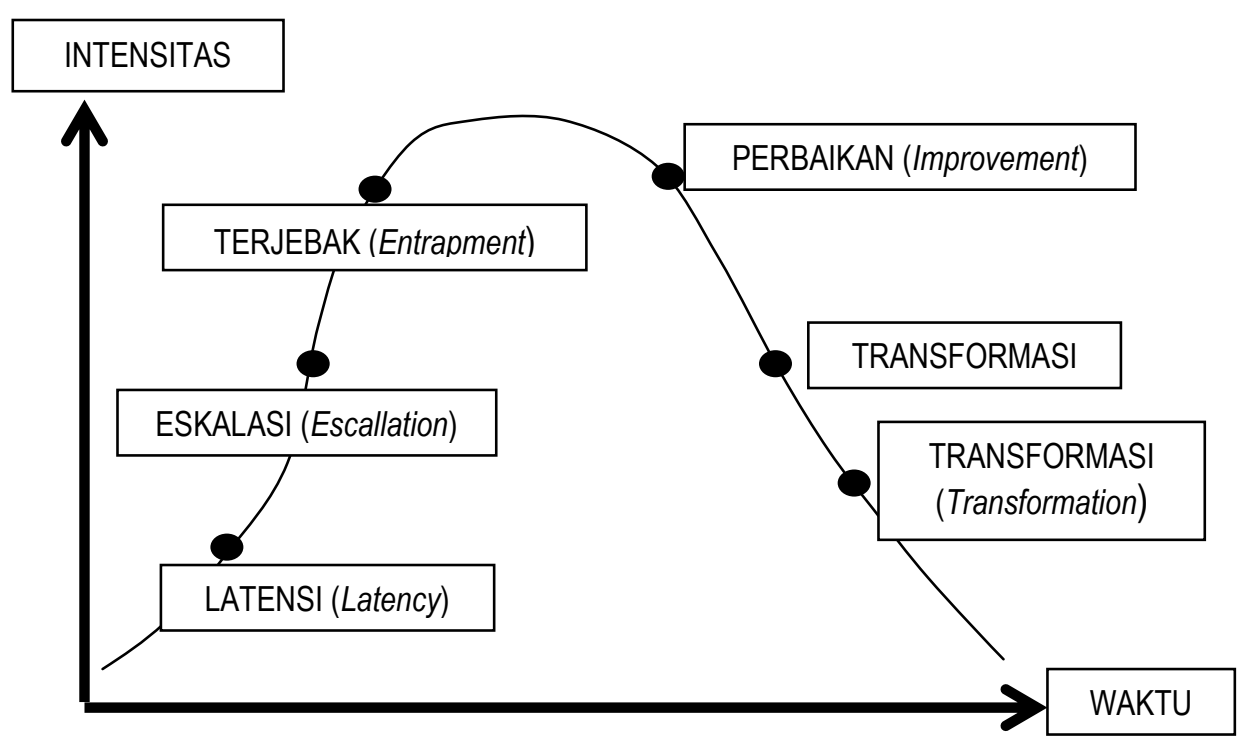

Sumber: Diadaptasi dari Craig Arendse, Robert Evans dan John C Nelson, Advanced Training for Mediation, SPP UKDW, Yogyakarta, 2000.

Sasaran rekonsiliasi harus mencakup partisan tingkat elite, menengah dan grass roots dari kalangan pihak-pihak, stake- holder, pihak netral dan pihak yang rawan karena adanya konflik (vulnerable groups). Kelompok terakhir ini perlu diperhatikan 
lebih serius untuk menarik mereka ke posisi netral. Yang berada di posisi netral dikembangkan menjadi kelompok inti rekonsiliasi untuk memperluas zona damai. Pengembangan kelompok inti bisa dilakukan dengan core group development approach.

Kelompok inti adalah kelompok yang berisikan warga yang bisa menjadi penggerak. Kelompok ini dimampukan terlebih dahulu dalam porsi yang lebih besar, meskipun jumlah mereka biasanya sedikit saat konflik mencapai fase keterjebakan. Pembekalan yang lebih baik bagi kelompok inti dilakukan agar kompetensi dan kepercayaan pada diri mereka tumbuh agar yakin bahwa mereka dapat berbuat untuk memperbaiki keadaan.

Setelah masyarakat jenuh karena jebakan konflik, maka upaya yang penting adalah pramediasi, yaitu mengajak partisan untuk menyelesaikan masalah bersama partisan lainnya di meja perundingan dalam bentuk negosiasi dan mediasi. Keduanya mempersyaratkan adanya kerjasama. Negosiasi adalah bertemu dan berundingnya para partisan untuk menyelesaikan konflik mereka tanpa kehadiran mediator. Mediasi adalah bertemu dan berundingnya para partisan untuk menyelesaikan konflik mereka melalui seorang mediator dengan tanggung jawab penyelesaian tetap pada masing-masing partisan dan mediator lebih sebagai fasilitator bagi pihak-pihak tersebut. Negosiasi dan mediasi membutuhkan diubahnya perbincangan tentang posisi partisan yang semula berhadapan ke arah pembicaraan kepentingan yang sama. Jika kesamaan kepentingan tidak tercapai, maka pembicaraan ditarik ke arah kebutuhan yang sama, yang meliputi kebutuhan primer, yaitu pangan, sandang, papan, keamanan dan identitas.

Cara mediasi bisa pula melalui sebuah diplomasi ulang alik yang dilakukan oleh mediator. Bisa pula dengan cara merancang sebuah naskah tunggal untuk didiskusikan oleh masing-masing partisan secara terpisah. Cara ini bisa dikombinasi dengan mengundang konferensi besar yang dihadiri oleh partisan, stakeholder partisan, dan pihak netral. Konferensi itu bisa diselenggarakan oleh pihak ketiga yang cakap dan memahami permasalahan konflik (Judo Poerwowidagdo, 2001). Tujuan konferensi besar, seminar dan semacamnya adalah memperluas persepsi para pihak untuk melihat persoalan konfliktual dalam bingkai kepercayaan, paradigma dan pengalaman yang lebih luas.

\section{Model Teoretik Rekonsiliasi}

Dalam kebanyakan literatur mengenai rekonsiliasi, masa lalu dipandang sebagai komponen terpenting untuk sampai kepada pemaafan terhadap kekekerasan dan kejahatan-kejahatan pada masa lalu. Walaupun dalam hal ini pemaafan secara sosial dan pemaafan secara individual tidak selalu berjalan paralel. Bisa saja seseorang memaafkan orang lain secara personal, tetapi tidak dalam tataran kelompok.

Dalam hal pemaafan secara sosial ini, komponen masa lalu dalam bentuk ingatan kolektif harus dipertimbangkan agar proses rekonsiliasi bisa tercapai. Montville (1991:1993) mengatakan bahwa tahap pertama workshop yang menandai rekonsiliasi justru membicarakan sejarah konflik tersebut.

Walaupun secara umum dipahami sebagai cara untuk mengakhiri konflik (resolusi konflik), rekonsiliasi sebagai istilah dan konsep tidak diartikan secara sama oleh para ilmuwan dan praktisi. Beberapa definisi mengartikan rekonsiliasi sebagai suatu peristiwa. Sebagian lagi menyatakan rekonsilasi sebagai proses dan hasil sekaligus. Beberapa peneliti lainnya beranggapan rekonsiliasi lebih tepat dipandang sebagai pemulihan hubungan. Umumnya, rekon- 
siliasi dimaknai sebagai suatu usaha untuk menyelesaikan konflik pada masa lalu sekaligus memperbarui hubungan ke arah perdamaian dan hubungan yang lebih harmonis pada masa yang akan datang.

\section{a) Teori Pilihan Rasional (rational choice model)}

Dasar teori ini adalah bahwa masyarakat ataupun aktor (atau individu yang bertindak atas nama kolektif), adalah pelaku yang rasional yang akan bertindak untuk mencapai hasil maksimal yang mungkin dari setiap interaksinya. Dalam konteks rekonsiliasi dapat dipahami sebagai tindakan atau keputusan terbaik yang menguntungkan semua pihak yang didapat dari suatu proses perundingan yang rasional.

Asumsi pengambilan keputusan secara rasional adalah sebagai berikut: 1) aktor mempunyai tujuan tertentu; 2) tujuan tesebut merefleksikan kepentingan aktor; 3) individu mempunyai kecenderungan yang konsisten dan stabil; 4) jika ada pelbagai macam pilihan, actor akan memilih alternatif yang akan memberikan keuntungan maksimal; 5) aktor dengan kepentingan politik adalah pemain terpenting (Long \& Brecke, 2003).

Menurut model pilihan rasional ini, keputusan untuk perang atau rekonsiliasi sangat ditentukan oleh pola pertukaran dan perhitungan untung-rugi (Long \& Brecke, 2003). Menurut model ini, pemulihan hubungan baik adalah konsekuensi dari tercapainya pilihan-pilihan rasional dalam suatu negosiasi untuk mencapai suatu penyelesaain konflik. Karena model ini sangat mengandaikan pada asumsi rasionalistik, segala sesuatu yang menyangkut kerugian harus bisa ditakar dan direkompensasi secara hitungan yang rasional.
Kritik terhadap pendekatan pilihan rasional ini adalah bahwa dalam soal pemulihan hubungan pascakonflik atau rekonsiliasi, pola pertukaran antara pihakpihak yang bertikai tidak selamanya bisa diukur secara rasional. Misalnya, sangat sukar untuk menentukan berapa pertukaran yang layak untuk kematian, cacat, trauma dan kerugian-kerugian psikologis lainnya. Keseimbangan rasional juga tidak selalu terjadi atas pilihan pertukaran yang diambil, seperti yang diasumsikan teori ini.

Kritik lain terhadap pendekatan teori pilihan rasional adalah pada pemahamannya yang sempit mengenai tindakan manusia. Asumsi-asumsi psikologis di balik teori ini adalah bahwa manusia selalu bisa menggunakan alternatif pilihan rasional sebaik mungkin, berpijak pada logika deduktif. Dalam kenyataannya, bahkan secara kognitif, pengambilan keputusan lebih banyak mengandalkan pada cara-cara yang cepat.

Persoalan lain adalah, teori ini mengabaikan faktor emosi dalam rekonsiliasi. Daya tarik teori pilihan rasional ini terletak pada kenyataan bahwa ia memungkinkan semua pihak untuk merundingkan aspek pemuasan kebutuhankebutuhan dasar seperti yang diisyaratkan oleh pendekatan teori kebutuhan (Burton, 1990).

\section{b) Teori Kebutuhan Manusia (Human Need Theory)}

Model rekonsiliasi ini bertolak dari kenyataan bahwa konflik yang berkepanjangan telah menimbulkan kondisi deprivasi, atau paling tidak marginalisasi dalam pemenuhan kebutuhan manusia yang mendasar (Burton, 1990). Oleh karenanya, rekonsiliasi menurut pandangan teori ini baru akan sukses jika momen rekonsiliasi bisa menjamin akan tercapainya pemenuhan kebutuhan-kebutuhan mendasar ini. 
Teori ini terinspirasi oleh teori Maslow mengenai dasar motivasi manusia. Proposisi utama yang disandang oleh teori ini adalah bagaimanapun motivasi manusia yang paling hakiki adalah pemenuhan kebutuhan dasar dan kebutuhan eksistensi. Dalam hal ini dorongan pemenuhan kebutuhan bisa menjadi dasar motivasi untuk melakukan rekonsiliasi, jika dipersepsikan bahwa rekonsiliasi bisa menjamin terpenuhinya keinginan kelompok untuk memperoleh kebutuhan-kebutuhannya.

Mengenai kebutuhan, Burton (1990) memberikan tiga label, yaitu kebutuhan, nilai-nilai, dan kepentingan. Kebutuhan dimaksudkan oleh Burton merujuk kepada kebutuhan universal seperti yang dimaksudkan Maslow, yaitu kelompok kebutuhan biologis. Sementara itu nilai-nilai dimaksudkan oleh Burton lebih kepada ide-ide, kebiasaan-kebiasaan, adat, dan kepercayaan-kepercayaan, yang menjadi ciri utama (identitas) suatu kebudayaan, etnik ataupun kelompok yang lebih bersifat simbolik, terikat konteks sosial dan budaya. Kepentingan dimaksudkan oleh Burton terkait dengan posisi, status dan peran seseorang atau kelompok dalam konteks pekerjaan, ekonomi dan politik. Proses negosiasi dalam rangka rekonsiliasi menurut Burton (1990) adalah menjaga keseimbangan pertukaran antara kebutuhan, nilai-nilai dan kepentingan-kepentingan.Dalam model rekonsilasi yang lebih terintegrasi, isu mengenai hal ini tercakup dalam pengertian kompensasi dan rekonstruksi.

c) Model Pemaafan (Forgiveness Model)

Model ini bertitik tolak dari asumsi bahwa rekonsiliasi adalah bagian dari proses pemaafan, atau proses transformasi emosi-emosi tertentu, misalnya marah, dendam, menjadi kedekatan, hubungan baik serta terciptanya etos berdamai. Dengan adanya proses transformasi ini terbukalah kemungkinan untuk memperbarui hubungan yang pernah buruk, dan ini hanya bisa tercapai melalui proses pemaafan (Long \& Brecke, 2003).

Model pemaafan ini jika dibandingkan dengan model-model sebelumnya, mempunyai beberapa keunggulan, terutama pada kemampuannya untuk mempertimbangkan faktor emosi dan penalaran sekaligus. Rekonsiliasi dipandang sebagai proses transformasi etos berkonflik menjadi etos berdamai. Kelemahan model ini terletak pada diperlukannya usaha yang sungguhsungguh untuk melaksanakannya, dan terkadang proses pemaafan baru bisa terjadi dalam jangka waktu yang cukup lama.

Di luar itu harus ada misalnya usahausaha untuk mengungkapkan kebenaran, proses penyembuhan/pemulihan dan pembenahan faktor struktural. Menurut Bar-Tal (2000:359), proses rekonsiliasi terutama harus menyentuh aspek psikologis yang terdalam pada masyarakat. Rekonsiliasi mensyaratkan perubahan-perubahan psikologis yang mendasar, yaitu proses transformasi dan sikap yang menyokong hubungan yang damai antara pihak-pihak yang bermusuhan. Harus terjadi perubahan etos dari etos berkonflik menjadi etos damai.

Perubahan etos ini hanya bisa terjadi jika adanya perubahan dalam masyarakat. Proses perubahan etos bukanlah proses yang mudah karena disebabkan oleh berbagai faktor, diantaranya proses rekonsiliasi terkadang belum tentu menjamin adanya kesembuhan atau pemulihan di tingkat individual, terkadang hanya terjadi pada tingkat kolektif atau sebaliknya. Faktor lain adalah sulitnya perubahan pada tingkat struktural. Namun salah satu faktor yang terpenting adalah bagaimana mengubah keyakinan mengenai hakikat hubungan antarkelompok yang dipenuhi oleh rasa permusuhan dan sudah tercetak dan tertanam dalam ingatan kolektif. Persoalan ini 
sangat terkait dengan penilaian tentang masa lalu.

Proses perubahan etos ini juga harus menyangkut mengenai konsepsi dan harapan tentang tujuan-tujuan masyarakat pada masa datang dan mengenai prospek perdamaian di masa mendatang. Dengan demikian, proses pemaafan tidak terjadi begitu saja, tapi melalui proses transformasi kesadaran. Long dan Brecke (2003) menggambarkan proses model pemaafan ini ke dalam empat fase, seperti bagan di bawah ini:

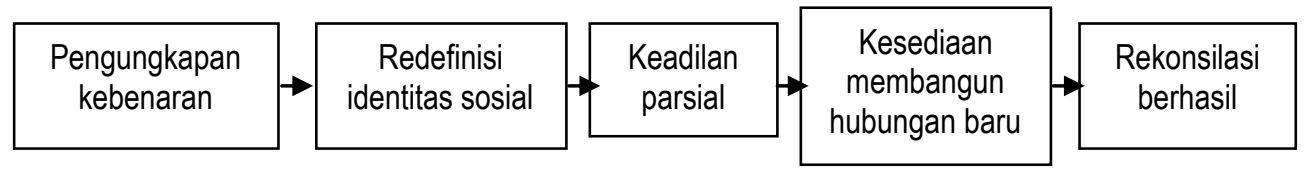

\section{Bagan 1. Model Pemaafan}

Pada fase pertama, kelompok yang berkonflik harus mau dan rela menyadari apa yang telah terjadi pada masa lalu. Setiap kelompok yang bertikai harus mau dan mampu menyadari kesalahan di masa lalu. Idealnya proses pengungkapan kebenaran harus terbuka untuk publik, misalnya melalui investigasi resmi, laporan di media massa. Memang harus disadari konsekuensi psikologik dari proses ini. Pelbagai macam reaksi bisa muncul dari proses ini; merasa malu, bersalah, dan perilaku agresif. Cara coping yang paling mungkin muncul, bisa dalam bentuk pengingkaran, agresivitas aktif (marah) atau pasif (dendam) atau bisa juga pemaafan. Pilihan untuk memaafkan mengharuskan semua pihak untuk menyadari terlebih dulu (bukan mengikari) apa-apa yang telah terjadi, mengapa terjadi, siapa yang melakukan, mengapa ia melakukan, apa kesalahannya (North, 1998:7).

Pada fase kedua, rekonsiliasi menghendaki kesediaan kelompok mengubah sudut pandangnya mengenai posisi dan identitas kelompok sendiri, posisi dan identitas kelompok lainnya. Redefenisi hubungan pasca konflik melibatkan sekaligus faktor kognitif dan emosi.
Ketiga, kelompok-kelompok yang dirugikan sungguhpun berhak untuk mendapat keadilan yang setimpal dengan apa yang telah diperbuat oleh pihak lain kepadanya sebelumnya, ataupun mempunyai kesempatan untuk membalas dendam, hendaknya bisa menyadari bahwa keadilan tidak akan bisa ditegakkan sepenuhnya. Apa yang bisa dicapai dalam soal keadilan ini, hanya sebatas pada yang disebut sebagai 'partial justice'. Penegakan dan pencarian keadilan dalam pengertian setuntas-tuntasnya tidak akan pernah didapat, yang penting dalam hal ini adalah adanya perhatian pada pemenuhan rasa keadilan.

Keempat, proses rekonsiliasi harus diakhiri dengan keinginan untuk membuat kontak lebih intens, jika perlu disertai dengan pemaafan secara publik atau secara sosial menawarkan hubungan yang lebih bagus, paling tidak hidup berdampingan secara damai, saling menghormati, dan saling toleran.

Proses rekonsiliasi menurut model pemaafan ini pada umumnya terjadi menurut fase-fase di atas, walaupun tidak selalu berjalan berurutan secara satu arah (linear). Kadang-kadang fase-fase tersebut berjalan secara berurutan, terkadang justru ber- 
langsung secara simultan dalam saat yang bersamaan.

\section{Metode Penelitian}

Penelitian ini termasuk jenis penelitian deskriptif kualitatif. Data diperoleh dari sumber primer dan sekunder. Data primer yang berupa keterangan atau fakta di lokasi penelitian diperoleh dari informan, dan peristiwa atau aktivitas yang terkait dengan topik penelitian. Data sekunder berupa dokumen dan arsip tentang objek penelitian, baik berupa dokumen sejarah dan profil objek, berita dan analisis media massa, serta data lain yang relevan.

Pengumpulan data primer dilakukan dengan teknik wawancara mendalam dan observasi langsung. Wawancara dilakukan dengan ketua dan pengurus organisasi silat Setia Hati Terate dan Setia Hati Winongo, pelaku peristiwa konflik, tokoh masyarakat, pemerintah daerah, aparat keamanan, serta masyarakat umum. Observasi langsung dilakukan terhadap tempat-tempat atau arena terjadinya peristiwa konflik. Data sekunder tentang objek penelitian diperoleh dengan mengumpulkan dokumen dan arsip yang ditemukan di lokasi penelitian.

Sampel informan dipilih secara selektif dan dilakukan secara mengalir dengan penyesuaian berkelanjutan sehingga semakin banyak narasumber semakin dipusatkan pada fokus studi. Pemilihan sampel berakhir jika telah terjadi perulangan. Pemilihan informan dapat berkembang sesuai dengan kebutuhan dan kemantapan peneliti dalam memperoleh data. Informan dipilih berdasarkan pengetahuan dan keterlibatan informan terkait dengan tema penelitian.

Validasi data dilakukan melalui teknik triangulasi sumber, yaitu dengan cara membandingkan data dari satu sumber data yang satu dengan sumber data yang lain, triangulasi teknik, yaitu membandingkan data dari satu teknik pengumpulan data dengan teknik yang lain, dan triangulasi peneliti, yaitu membandingkan data yang diperoleh anggota tim peneliti dengan anggota peneliti yang lain.

Analisis data dilakukan dengan metode analisis data kualitatif. Analisis data ditujukan pada data-data yang sifatnya kualitas dan sifat yang nyata diterapkan di lokasi penelitian. Ada dua cara yang digunakan dalam penelitian ini, yaitu analisis isi dan analisis interaktif. Untuk data dokumen dan arsip digunakan analisis isi, sedangkan untuk data hasil wawancara dan observasi digunakan analisis interaktif, seperti dikemukakan Milles dan Huberman (1996). Ada tiga komponen analisis yaitu: reduksi data sajian data dan penarikan kesimpulan. Aktivitas ketiga komponen dilakukan dalam bentuk interaktif dengan proses pengumpulan data sebagai suatu proses siklus. Peneliti hanya bergerak diantara tiga komponen analisis tersebut sesudah pengumpulan data selesai pada setiap unitnya dengan memanfaatkan waktu yang masih tersisa dalam penelitian ini. Untuk lebih jelasnya proses analisis interaktif dapat digambarkan dalam skema sebagai berikut.

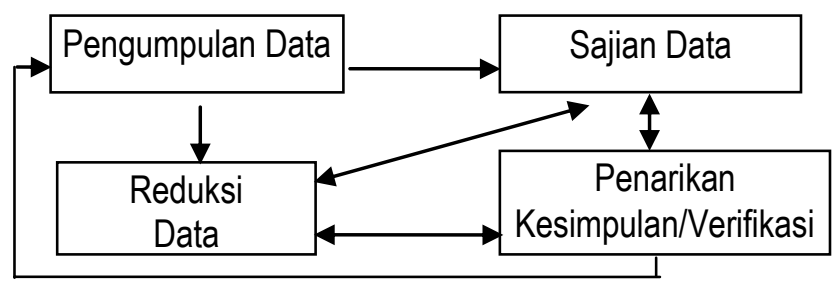




\section{Bagan 2 Analisis Data Interaktif}

Data mentah yang terkumpul di lokasi penelitan direduksi, disusun lebih sistematis, dipilih pokok yang penting, difokuskan dan dicari tema dan polanya. Selanjutnya dilakukan reduksi data, yaitu pemilihan, pemusatan perhatian pada penyederhanaan, pengabstrakan, dan transformasi data kasar yang muncul dari catatan-catatan tertulis di lapangan. Sistematisasi data dilakukan dengan membuat sajian data yang berupa tabel, jaringan, atau bagan. Dari sistematisasi data tersebut akan ditemukan pokok-pokok temuan yang penting, tema dan pola yang secara konsisten diterapkan di lokasi penelitian. Temuan-temuan tersebut dijadikan acuan dalam menarik kesimpulan.

\section{Hasil Penelitian dan Pembahasan}

\section{A. Hasil Penelitan}

\section{Akar Konflik}

Konflik antara Persaudaraan Setia Hati Terate dengan Setia Hati Winongo Tunas Muda tidak lepas dari latar sejarah kedua perguruan silat tersebut. Pada mulanya, keduanya merupakan satu perguruan, yaitu Perguruan Setia Hati. Perguruan Setia Hati sendiri berawal dari perkumpulan pencak silat yang anggotanya disebut "Sedulur Tunggal Kecer" yang didirikan oleh Ki Ngabei Soerodiwiryo dari Madiun pada hari Jumat Legi 10 Syuro 1323 $\mathrm{H}$ atau tahun $1903 \mathrm{M}$ di Kampung Tambak Gringsing Surabaya.

Ki Ngabehi Soerodiwirjo sebagai tokoh pendiri merupakan sosok sentral dalam Perguruan Setia Hati. Persaudaraan Setia Hati Terate dan Setia Hati Winongo Tunas Muda sama-sama masih menjunjung tinggi Ki Ngabehi. Setiap anggota baru yang masuk diperkenalkan dulu dengan tokoh pendiri tersebut.

Ki Ngabehi Soerodiwirjo terlahir dengan nama Muhammad Masdan pada hari Sabtu Pahing 1869, bulannya tidak diketahui. Ayahnya bernama Ki Ngabehi Soeromiharjo yang bekerja sebagai Mantri Cacar di Ngimbang Lamongan. Ki Ngabehi Soeromiharjo dikaruniai 5 (lima) putera yaitu: Ki Ngabehi Soerodiwiryo (Masdan), Noto (Gunari) di Surabaya, Adi (Soeradi) di Aceh, Wongsoharjo di Madiun, dan Kartodiwirjo di Jombang (Soewarno, 1994:18).

Di masa mudanya, Ki Ngabehi Soerodiwirjo merupakan sosok pengelana yang haus akan ilmu. la sangat mencintai budaya Indonesia, termasuk seni bela diri pencak silat Nusantara. la juga dikenal sebagai sosok yang religius sehingga perguruan pencak silatnya penuh dengan muatan-muatan keagamaan.

Pada tahun 1883, saat berusia 14 tahun, $\mathrm{Ki}$ Ngabehi Soerodiwirjo lulus Sekolah Rakyat 5 tahun. Selanjutnya ikut Pakde, Mas Ngabehi Soeromiprojo yang menjabat sebagai Wedono Wonokromo yang kemudian pindah dan menjabat lagi sebagai Wedono Sedayu Lawas, Surabaya.

Setahun setelah lulus Sekolah Rakyat, Ki Ngabehi bekerja sebagai juru tulis di Kantor Kontrolis Jombang. Sambil belajar mengaji, Ki Ngabehi belajar pencak silat yang di kemudian hari menjadi dasar dari kegemarannya memperdalam pencak silat. Pada tahun 1885 pindah kerja magang di kantor Kontrolir Bandung. Disini ia juga belajar pencak silat dari pendekar-pendekar Priaangan, sehingga memperoleh jurusjurus seperti: Cimande, Cikalong, Cipetir, Cibeduyut, Cimelaya, Ciampas, dan Sumedangan. Pada tahun 1886 pindah ke Betawi (Jakarta) dan memperdalam pencak silat sampai akhirnya menguasai jurus-jurus seperti: Betawen, Kwitang, Monyetan, dan Permainan Toya (Stok spel). Pada tahun 
1887 ikut Kontrolir Belanda ke Bengkulu dan disana juga belajar pencak silat yang gerakannya mirip seperti jurus-jurus di daerah Jawa Barat.

Pada pertengahan tahun 1887, Ki Ngabehi ikut Kontrolir Belanda pindah ke Padang dan tetap bekerja pada bidang pekerjaan yang sama. Di daerah Padang Hulu dan Padang Hilir, ia tetap memperdalam pencak silat yang gerakannya berbeda dengan pencak silat dari daerah Jawa Timur, Jawa Tengah dan Jawa Barat. Di daerah tersebut, Ki Ngabehi berguru kepada seorang pendekar dan guru ilmu kebatinan yang bernama Datuk Raja Betua dari Kampung Alai Kecamatan Pauh Kota Padang. Ki Ngabehi belajar pencak silat kepada Pendekar Datuk Raja Betua selama 10 (sepuluh) dan memperoleh tambahan jurus-jurus dari daerah Padang, yaitu: Bungus, Fort de Kock, Alang Lawas, Lintau, Alang, Simpai, dan Sterlak. Sebagai tanda lulus, Ki Ngabehi mempersembahkan hadiah kepada gurunya tersebut berupa pakaian hitam-hitam.

Pada tahun yang sama, saat berusia 28 tahun, Ki Ngabehi jatuh cinta kepada seorang gadis Padang, puteri seorang ahli tasawuf. Untuk mempersunting gadis tersebut, ia harus dapat menjawab pertanyaan, "Siapakah sesungguhnya Masdan dan siapakah sesungguhnya saya ini?" (gadis pujaan itu?). Ki Ngabehi tidak dapat menjawab pertanyaan tersebut berdasarkan pikirannya sendiri sehingga berguru kepada seorang ahli kebatinan yang bernama Nyoman Ida Gempol, seorang Punggawa Besar dari Kerajaan Bali yang dibuang Belanda ke Sumatra (Padang). IImu yang diperoleh dari Nyoman Ida Gempol terangkum dalam motto: "gerak lahir luluh dengan gerak batin", "gerak batin tercermin oleh gerak lahir."

IImu kebatinan yang diperoleh dari Nyoman Ide Gempol digabungkan dengan pencak silat serta ilmu kebatinan yang didapat dari Datuk Raja Betua. Berbekal keilmuan tersebut, Ki Ngabehi berhasil menjawab pertanyaan gadis pujaannya dan mempersuntingnya. Dari pernikahan ini, Ki Ngabehi tidak dikarunian keturunan.

Pada tahun 1898, Ki Ngabehi bersama istri pergi ke Aceh dan bertemu adiknya Soeradi yang menjabat sebagai Kontrolir DKA di Lhok Seumawe. Di daerah ini, Ki Ngabehi mendapatkan jurus-jurus seperti: Jurus Kucingan, Jurus Permainan Binja. Selanjutnya pada tahun 1900, Ki Ngabehi Soerodiwirjo kembali ke Betawi bersama isteri dan bekerja sebagai Masinis Stoom Wals. Disini, Ki Ngabehi Soerodiwirjo bercerai dengan isterinya. Istrinya kemudian kembali ke Padang dan Ki Ngabehi sendiri pindah ke Bandung.

Setelah tiga tahun di Bandung, pada tahun 1903 Ki Ngabehi kembali ke Surabaya dan menjabat sebagai Polisi Dienar hingga mencapai pangkat Sersan Mayor. Di Surabaya, Ki Ngabehi dikenal keberaniannya dalam memberantas kejahatan. Dan pada tahun inilah Ki Ngabehi mendirikan Persaudaraan "Sadulur Tunggal Kecer".

Pada tahun 1912, Ki Ngabehi berhenti dari Polisi Dienar bersamaan dengan meluapnya rasa kebangsaan Indonesia yang dimulai sejak tahun 1908. Ki Ngabehi kemudian pergi ke Tegal dan ikut seorang paman dari almarhum saudara Apu Suryawinata yang menjabat sebagai Opzichter Irrigatie.

Pada tahun 1924, Ki Ngabehi dan isterinya Nyi Sarijati pindah ke Madiun, tinggal menetap di Desa Winongo dan bekerja di Magazijn D.K.A. Madiun. Ki Ngabei Soerodiwiryo menikah dengan Nyi Sarijati pada tahun 1905 dan dikaruniai 3 (tiga) orang putera dan 2 (dua) orang puteri, namun semuanya meninggal sewaktu masih kecil. 
Di Madiun, Ki Ngabehi mengaktifkan kembali perkumpulan "Sedulur Tunggal Kecer" yang didirikannya di Surabaya. Nama pencak silatnya saat itu disebut "Djojo Gendilo Tjipto Muljo". Pada tahun 1917, pencak silat ini mulai populer setelah melakukan demonstarsi secara terbuka di alun-alun Madiun. Masyarakat menyaksikan dengan antusias karena gerakannya yang unik, penuh seni, dan bertenaga. Pada tahun yang sama "Djojo Gendilo Tjipto Muljo" diganti namanya dengan "Setia Hati" yang disingkat $\mathrm{SH}$ agar sesuai dengan keadaan zaman (Singgih, 1963:10). Perkembangan keanggotaannya saat itu masih relatif lambat karena keanggotaannya terbatas pada kalangan kerabat dan kawankawan terdekat.

Salah satu diantara murid Ki Ngabei adalah Ki Hadjar Hardjo Oetomo. Melihat potensi "Setia Hati", Ki Hadjar ingin menyebarkan ilmu Setia Hati ke masyarakat luas hingga ke lapisan bawah. Gagasan ini terkendala oleh doktrin bahwa penyebaran ilmu SH tidak bisa dilakukan kepada semua orang dan di semua tempat (Maksum, 2009:105).

Ki Hadjar Hardjo Oetomo juga ingin menjadikan Perguruan Setia Hati sebagai alat perjuangan melawan penjajahan. $\mathrm{Ki}$ Hadjar kemudian memberanikan diri mendirikan perguruan dengan nama Setia Hati Pencak Sport Club pada tahun 1922 di tanah kelahirannya di Desa Pilangbangau Madiun. Perguruan tersebut merupakan cikal bakal perguruan silat yang kini dikenal dengan Persaudaraan Setia Hati Terate. Ki Ngabei Soerodiwiryo tidak secara eksplisit melarang atau merestuinya karena itu dianggap sebagai tanggung jawab pribadi $\mathrm{Ki}$ Hadjar (Maksum, 2009:105).

Pada tahun 1933, Ki Ngabehi Soerodiwirjo pensiun dari jabatannya dan berkonsentrasi mengelola perguruan. Pada tahun, 1944 Ki Ngabei memberikan pelajaran di Balong Ponorogo kepada Koesni dan Soerjatjaroko. Kegiatan tersebut menjadi pelajaran terakhir yang diberikannya karena kemudian ia jatuh sakit dan wafat pada hari Jumat Legi 10 November 1944 di rumah kediamannya di Winongo.

Sebelum wafat, $\mathrm{Ki}$ Ngabei Soerodiwiryo berpesan agar dibacakan ayat suci Alquran. Untuk memenuhi pesan tersebut, Naib Jiwan sat itu membacakan membacakan Surat al-Qadr yang pokokpokok isinya tentang turunnya wahyu AlQuran pada malam Lailatul Qadar. Ki Ngabei Soerodiwiryo juga berpesan agar saudara-saudara Setia Hati tetap bersatu hati, tetap rukun lahir bathin dan memberi maaf kepadanya dengan tulus ikhlas. Pesan lain dari Ki Ngabei berwasiat adalah agar rumah dan pekarangannya diwakafkan kepada Setia Hati dan selama Nyi Ngabei Soerodiwiryo masih hidup tetap menetap di rumah tersebut.

Sepeninggal Ki Ngabehi, SH yang berpusat di kediaman Ki Ngabehi diketuai oleh Koesnendar yang kini dikenal dengan Persaudaraan Setia Hati Panti. Persaudaraan Setia Hati Panti merupakan sebutan bagi Persaudaraan Setia Hati yang berada di Panti, yaitu di Rumah kediaman Ki.Ngabehi Soerodiwirjo di Jl. Gajah Mada No. 14 Winongo Kecamatan Manguharjo Kota Madiun. SH Panti hingga saat ini tidak masuk IPSI dan hanya merupakan paguyuban.

Sampai dengan tahun 1960-an, perkembangan SH Panti kurang menggembirakan karena kurangnya penerimaan anggota baru dan beberapa anggota senior wafat. Kalangan muda di SH Panti berinisiatif untuk membangkitkan kembali Perguruan Setia Hati. Pada tanggal 15 Oktober 1965, R. Djimat Hendro Soewarno mendirikan Persaudaraan Setia Hati Winongo Tunas Muda (Soewarno, 1994:99). Perguruan ini berpusat di kediamannya yang juga berada 
di Kelurahan Winongo Madiun. Namun demikian, meski sama-sama berpusat di Winongo, SH Winongo Tunas Muda dan SH Panti tidak ada hubungan organisatoris.

Lacakan sejarah di atas memperlihatkan dinamika internal di Perguruan Setia Hati yang berakibat pada perpecahan. Perpecahan tersebut disebabkan perbedaan strategi pengembangan perguruan. $\mathrm{Ki}$ Ngabehi ingin mengawal secara ketat perkembangan perguruan Setia Hati. Ki Ngabehi ingin agar ilmu Setia Hati tetap terjaga kualitasnya sehingga sangat selektif dalam menerima anggota baru. Sementara itu, Ki Hadjar Hardjo Oetomo ingin agar Setia Hati lebih terbuka sehingga dapat lebih mudah diterima di kalangan masyarakat luas. Demikian pula R. Djimat Hendro Soewarno dengan Setia Hati Winongo Tunas Mudanya juga ingin mengembangkan perguruan dengan lebih terbuka seperti halnya SH Terate. Sampai tahap tersebut, dinamika hubungan antara ketiga $\mathrm{SH}$ tersebut tidak diwarnai konflik terbuka dan nirkekerasan. Kedua perguruan tersebut saling berdampingan dengan damai.

Benih konflik kekerasan mulai mengemuka ketika beberapa pendekar $\mathrm{SH}$ Winongo dan SH Terate terlibat dalam konflik politik pasca Peristiwa 30 S 1965. Beberapa pendekar dari kedua perguruan terlibat bentrok fisik karena peristiwa politik tersebut, meskipun kedua perguruan silat sebenarnya tidak berafiliasi ke salah satu partai politik. Sejak saat itu mulai sering terjadi perkelahian antarpendekar di berbagai pelosok Madiun. Perkelahian yang juga melibatkan senjata tajam tersebut tidak jarang berakhir dengan kematian salah satu pihak. Madiun saat itu bagaikan zona perang para pendekar silat. Di berbagai sudut kota dan kampung tugu dan terdapat grafiti yang menunjukkan identitas kelompok pendekar yang menguasai kawasan tersebut. Pendekar SH Terate menggunakan istilah
SHT (Setia Hati Terate) untuk menandai basisnya. sementara SH Winongo menggunakan istilah STK (Sedulur Tunggal Kecer). SH Winongo Tunas Muda memiliki basis kuat di daerah Madiun kota, sementara SH Terate mengakar di daerah Madiun kabupaten.

Pada era tahun 1990-an banyak anggota baru yang masuk, terutama dari kalangan remaja usia 17 tahun. $\mathrm{Di} \mathrm{SH}$ Winongo, sebelum menjadi anggota, mereka "dikecer" dulu rohaninya dan setelah lulus dari "keceran" tersebut barulah disahkan menjadi "saudara" di bawah sumpah perguruan dan berhak mendapat pendidikan dan latihan silat. Pencak silat hanyalah daya tariknya, yang terpenting adalah kerohaniannya. Oleh karena itu, SH Winongo tidak punya padepokan. Kantor pusat adalah rumah pribadi almarhum pendiri R. Djimat Hendro Soewarno. Anggota baru masuk melalui pengurus ranting dengan disertai ijin dari orang tua, tidak langsung ke pusat. Usia minimal 17 tahun dengan asumsi sudah memasuki usia dewasa sehingga secara psikologis sudah stabil. Anggota baru tidak dipungut biaya, hanya uang masuk sebesar Rp $60.000,00$ yang itu pun pada akhirnya untuk kepentingan anggota sendiri. Pelatih pun tidak dibayak karena ketika latihan juga tidak membayar (Agus Winarno, 8 September 2011). Strategi tersebut berbeda dengan di SH Terate. Anggota baru dapat disahkan menjadi "warga" setelah melalui "keceran" yang cukup lama, baik fisik maupun rohani.

Keberadaan anggota baru dari kalangan remaja tersebut menjadi tantangan bagi kedua perguruan. Status sebagai pendekar merupakan kebanggan tersendiri bagi mereka di tengah proses pencarian jati diri. Mereka seringkali mudah terpancing emosi dan mengabaikan kode etik atau sumpah perguruan. Peristiwa kecil saja dapat memicu bentrok fisik, tidak saja 
perorangan, melainkan melibatkan massa pendukung kedua perguruan karena rasa solidaritas sehingga menjadi kekerasan massal.

Di SH Winongo, anggota yang melanggar sumpah, maka Tuhanlah yang akan menghukumnya sendiri sesuai dengan sumpah yang telah diucapkan. Pelanggaran itu dianggap sebagai penyimpangan dan risiko ditanggung anggota sendiri (risiko ditanggung penumpang). Pihak organisasi hanya menegur dan berusaha meluruskan saja. Tidak ada istilah pemecatan sekalipun telah menyatakan keluar karena sudah satu sumpah. Kalau yang bersangkutan sakit misalnya, tetap ditengok karena dianggap tetap masih saudara. Apabila pelanggaran tersebut telah menyangkut perkara hukum, maka diserahkan kepada aparat penegak hukum (Wawancara dengan Agus Winarno, 8 September 2011).

Demikian pula di SH Terate. Anggota yang terlibat bentrokan diserahkan kepada aparat penegak hukum dan menjadi tanggung jawab pribadi anggota. SH Terate tidak akan intervensi apabila memang dia benar-benar bersalah. Namun demikian, $\mathrm{SH}$ Terate tetap menjenguknya apabila dia dipenjara (Wawancara dengan Tarmadji Boedi Harsono 4 Mei 2011).

Para pengurus pusat kedua perguruan silat tersebut menolak apabila diantara mereka disebut-sebut berkonflik. Menurut mereka, SH Terate dan SH Winongo adalah saudara. "Kami tidak ada masalah dengan perguruan lain," kata Ketua Umum PSH Terate H. Tarmadji Boedi Harsono (Wawancara 4 Mei 2011). "Kami tidak ada musuh bebuyutan, dan kami tidak pernah mengajari tentang adanya musuh bebuyutan pada anggota baru. Musuh kami adalah setan," kata Ketua PSH Winongo, Agus Winarno (Wawancara 8 September 2011).
Konflik kekerasan yang melibatkan massa pendukung kedua perguruan merupakan kenyataan yang tidak terbantahkan. Menurut Ketua Umum PSH Terate H. Tarmadji Boedi Harsono, fenomena itu dapat dibaca sebagai fenomena kenakalan remaja yang pada akhirnya nanti akan berhenti sendiri secara alamiah. (Wawancara 4 Mei 2011). Sementara Ketua PSH Winongo Agus Winarno menilai bahwa bentrok antara dua perguruan silat tersebut dimotori oleh pihakpihak yang tidak bertanggung jawab untuk kepentingan pribadi. Hal ini terbukti, saat tidak berlangsungnya Suran Agung, hubungan keduanya cukup baik dan tidak ada bentrokan. Konflik biasanya terjadi setiap ada even, seperti Suran Agung. PSH Winongo pernah kami mendapat SMS yang memberitahukan bahwa mereka akan dihadang di daerah Sukolilo, akan tetapi ternyata berita itu tidak benar (Wawancara, 8 September 2011).

\section{Arena Konflik \\ a. Suran Agung}

Suran Agung merupakan salah satu ritual yang wajib dilakukan oleh perguruan silat PSH Winongo Tunas Muda yang diadakan setiap bulan Muharam dalan kalender Hijriah atau bulan Sura dalam kalender Jawa. Kegiatan ini dipusatkan di jalan Doho Kelurahan Winongo Kecamatan Manguharjo Kota Madiun. Suran Agung dihadiri oleh anggota dari kota/kabupaten, bahkan dari luar negeri.

Perayaan Suran Agung tidak lepas dari tradisi selamatan masyarakat Jawa dalam menyambut bulan Sura atau Muharam. Pada awalnya diselenggarakan dengan sederhana pada masa Ki Ngabehi Soerodiwirjo masih hidup, yaitu dengan membuat "bubur Suro" yang dianggap cukup memenuhi kebutuhan. Selain untuk menikmati hidangan selamatan yang sederhana 
itu juga untuk memperingati pergantian tahun baru, mengadakan "sambung" yang sifatnya bukan latihan, melainkan untuk menunjukkan rasa gembira menyambut bulan Sura. Sura sendiri berasal dari kata bahasa Arab "As-syura" yang berarti musyawarah. Makna musyawarah bulan Sura tersebut direalisasikan dengan permainan "sambung menyambung menjadi satu", satu pendapat, dari sepakat menjadi mufakat (Singgih dkk, 1963:24).

Pada mulanya Perayaan Suran dihadiri oleh para anggota yang berdomisili di Kota Madiun, namun sejak tahun 1931 dihadiri oleh anggota-anggota dari luar Kota Madiun dan diadakan pula di luar Kota Madiun karena sekaligus untuk memperingati ulang tahun berdirinya Persaudaraan Setia Hati. Peringatan di Kota Madiun saat itu menjadi penting karena merupakan kesempatan untuk bertemu dengan $\mathrm{Ki}$ Ngabehi Soerodiwirjo. Melalui Perayaan Suran tersebut diharapkan agar tali persaudaraan dapat semakin dipererat dan diperkokoh sehingga dijadikan tradisi yang melembaga setiap tahun. Peringatan Suran mulai dilakukan secara besar-besaran sejak tahun 1950 sepeninggal Ki Ngabehi Soerodiwirjo pada tahun 1944 dan setelah sempat dihentikan karena pada masa agresi militer Belanda kedua (Singgih dkk, 1963:25).

Setelah acara Suran Agung biasanya massa anggota Persaudaraan Setia Hati Tunas Muda Winongo dari berbagai daerah langsung mengadakan konvoi di jalan protokol Kota Madiun dengan kostum hitamhitam. Massa berputar mengelilingi Kota Madiun, sebelum akhirnya kembali ke daerah masing-masing. Agenda tahunan inilah yang menjadi salah satu momentum yang rawan konflik. Konvoi pada momentum-momentum tersebut sering terjadi bentrok massal di sepanjang rute yang dilewati.
Pada tanggal 13 Februari 2006 bertempat di Padepokan SH Winongo Jl. Doho No. 123 Kelurahan Winongo Kecamatan Manguharjo Kota Madiun telah dilaksanakan Suran Agung yang diikuti oleh \pm 7.000 orang, saat konvoi selesai kegiatan Suran Agung rombongan dari cabang Ngawi \pm 30 orang dihadang oleh 10 anggota warga SH Terate sehingga terjadi perkelahian massal yang mengakibatkan 7 orang mengalami luka parah.

Pada tanggal 19 Februari 2007 bertempat di Padepokan SH Winongo Jl. Doho No. 123 Kel. Winongo Kec. Manguharjo Kota Madiun telah dilaksanakan Suran Agung yang diikuti oleh \pm 6.500 orang, saat konvoi selesai kegiatan Suran Agung rombongan dari cabang Magetan \pm 30 orang dilempari batu oleh orang yang tidak dikenal sehingga mengakibatkan 5 orang luka parah.

Pada momentum menyambut Tahun Baru Jawa 1 Suro dan Hijiyah 1 Muharram 1430 atau pada Senin 29 Desember 2008 ribuan pendekar pencak silat dari SH Terate menggelar konvoi. Selain itu, mereka juga berziarah di makam leluhur pendekar Terate di kawasan Kelurahan Pilangbangu dan Taman. Konvoi pendekar Terate tersebut dihadang puluhan pemuda di depan kantor PLN Manisrejo. Sebagian pendekar turun dari mobil pick up dan mengambil bebatuan yang ada di sekitar lokasi dan melemparkan ke sekumpulan pemuda yang menghadangnya. Tidak ada korban jiwa, tetapi 13 pemuda yang diduga terlibat bentrok ditangkap aparat keamanan (detiksurabaya. com, diunduh 20 Agustus 2011).

Pada tanggal 18 Januari 2009 di padepokan SH Winongo telah dilaksanakan Suran Agung yang diikuti oleh \pm 6.200 orang, saat konvoi setelah kegiatan tepatnya di Jl. Setiabudi dilempari batu oleh beberapa orang yang tidak dikenal identitasnya sehingga mengakibatkan 3 orang meng- 
alami luka-luka di bagian dada dan kepala. Pada tanggal 19 Desember $2010 \mathrm{di}$ Padepokan SH Winongo Jl. Doho 123 Kel. Winongo Kec. Manguharjo Kota Madiun telah dilaksanakan Suran Agung yang diikuti oleh \pm 11.000 orang, saat konvoi selesai kegiatan terjadi beberapa kejadian:

1) Di Jl Ngebong depan gapura Perumnas Panorama Wilis telah terjadi perkelahian namun dapat dibubarkan oleh aparat keamanan dan tidak ada korban jiwa maupun materiil.

2) Di Desa Sangen Kecamatan Geger Kabupaten Madiun telah terjadi pelemparan dan penghadangan terhadap konvoi Suran agung yang hendak pulang, peristiwa ini tidak ada korban dan dapat diatasi oleh aparat keamanan (Made Gerina Yasa, 2011).

\section{b. Halal Bihalal}

Perguruan Persaudaraan Setia Hati Tunas Muda Winongo setiap tahun juga menyelenggarakan kegiatan halal bihalal yang dipusatkan di Kantor Pusat Jalan Doho, Kelurahan Winongo, Kecamatan Manguharjo, Kota Madiun. Ribuan orang anggota dari seluruh cabang yang ada di eks-Keresidenan Madiun menghadiri kegiatan tersebut. Selain anggota juga diundang seluruh jajaran pejabat pemerintahan, Polri, TNI, dan tokoh masyarakat di Madiun dan sekitarnya.

Acara Halal bihalal merupakan ajang silaturahmi antarsaudara sesama anggota PSH Winongo Tunas Muda, sehingga selalu ramai saat. Untuk mengamankan kegiatan tersebut, Polres Madiun Kota mengerahkan seluruh kekuatan yang ada dengan bantuan beberapa polres lainnya. Pengamanan dilakukan untuk mengantisipasi gangguan keamanan, terutama bentrok antaranggota perguruan silat, terutama di Padepokan Pusat PSH Tunas Muda Winongo. Personel lainnya bersiaga di berbagai lokasi mulai dari jalan yang dilalui peserta Halal bihalal hingga fasilitas umum, dan tempat vital lainnya. Para anggota PSH Winongo Tunas Muda pun biasanya dihimbau untuk tidak melakukan tindakan anarkis dan tetap menjaga ketertiban umum (Wawancara dengan Agus Winarno, 8 September 2011).

Pada momentum Halal bihalal selama lima tahun terakhir (2005 - 2010) terjadi beberapa insiden bentrokan. Pada tanggal 20 November 2005 bertempat di Padepokan SH Tunas Muda Winongo telah dilaksanakan Halal bihalal yang diikuti oleh \pm 2.500 orang. Saat itu terjadi beberapa insiden. Di jalan raya Nglames telah terjadi insiden pelemparan batu terhadap rombongan SH Winongo dilakukan oleh 25 orang yang belum diketahui identitasnya sehingga menimbulkan korban luka di pihak $\mathrm{SH}$ Winongo. Di Desa Kertobanyon Kecamatan Geger Kabupaten Madiun telah terjadi pelamparan batu yang dilakukan oleh rombongan $\mathrm{SH}$ Winongo terhadap toko Walisongo yang mengakibatkan kaca dan isi toko rusak dan menimbulkan 2 orang karyawan toko luka parah. Di Jalan Raya Jiwan Desa Sukolilo Kecamatan Jiwan Kabupaten Madiun telah terjadi pemukulan/pengeroyokan yang dilakukan oleh sekelompok orang yang belum diketahui identitasnya terhadap pengendara sepeda motor atas nama Pramono warga $\mathrm{SH}$ Winongo yang mengakibatkan luka serius di kepala sehingga dilarikan ke Rumah Sakit (Made Gerina Yasa, 2011).

Pada Halal bihalal 11 September 2011 juga terjadi insiden. Konvoi SH Winongo hampir bentrok dengan sekelompok warga dari organisasi pencak silat lainnya. Saat melewati jalan raya MadiunPonorogo, tepatnya di Desa Sangen, Kecamatan Geger, para pendekar tersebut hampir saja bentrok apabila polisi tidak dapat mencegahnya dengan menyuruh para warga untuk kembali ke dalam desa mereka 
serta menjauh dari jalan raya yang dilalui konvoi (Metrotvnews.com, diunduh 12 September 2011).

\section{c. Pengesahan Anggota Baru}

Setiap tahun, SH Terate mengesahkan anggota-anggota barunya menjadi "warga". Momentum ini juga rawan konflik karena anggota SH Terate yang berkumpul mencapai ribuan. Pada tanggal 16 Februari 2007 di Padepokan SH Terate Jl. Merak Kota Madiun telah dilaksanakan pengesahan warga baru yang diikuti \pm 5.400 orang. Setelah selesai pengesahan mengadakan konvoi dan dihadang oleh sekelompok orang yang tidak dikenal dan terjadi perkelahian sehingga menimbulkan 4 orang korban luka parah.

Pada tanggal 10 Januari 2008 di Makam Hardjo Utomo Kelurahan Pilangbango Kecamatan Kartoharjo Kota Madiun dan makam Imam Supangat Kelurahan Taman Kota Madiun telah dilaksanakan tabur bunga oleh SH Terate sejumlah \pm 5.500 orang telah terjadi beberapa insiden.

Di JI Sudirman di depan toko Niagara terjadi perampasan helm dan pengeroyokan terhadap Suyanto sehingga mengakibatkan luka serius. Di depan Stasiun Kereta Api Madiun telah terjadi perampasan helm dan pemukulan terhadap Fika Nugroho yang mengakibatkan luka ringan. $\mathrm{Di}$ Desa Banjarsari telah terjadi pelemparan rumah milik Gondo dan pemukulan terhadap tiga orang pemuda yang berada di rumah Gondo yang mengakibatkan ketiga orang tersebut luka parah (Made Gerina Yasa, 2011).

\section{Arena Integrasi}

Setiap tahun Pemerintah Kabupaten Madiun menyelengggarakan Festival Pencak Seni Tradisi pada momemtun Hari Jadi Pemkab. Semua perguruan silat terwakili termasuk Perguruan Setia Hati Terate dan Winongo. Kompetisi di festival bukan untuk mewakili atau mempertahankan perguruan, melainkan mewakili kecamatan. Festival Pencak Silat Seni Tradisi dimaksudkan untuk menggali dan meningkatkan prestasi dan kreatifitas secara keseluruhan dari peserta. Disamping itu juga untuk mencari bibit-bibit atlit yang baik, berbakat agar meraih prestasi di tingkat yang lebih tinggi baik regional maupun nasional.

Pada peringatan Hari Jadi Kabupaten Madiun ke 443 tahun 2011 ini dikuti sebanyak 120 orang atlet pesilat handal dari 15 Kecamatan di Kabupaten Madiun dengan kategori lomba perorangan, berpasangan dan kategori berkelempok. Peserta utusan dari 15 Kecamatan se Kabupaten Madiun sebanyak 120 pesilat terbagi menjadi tiga kategori yaitu perorangan, berpasangan, dan berkelompok untuk mencari penampilan terbaik I, II, dan III dari masing masing kategori dan akan mendapatkan piala, piagam dan uang pembinaan serta juara umum memperebutkan piala bergilir Bupati Madiun. Festival pencak silat berpotensi menjadi media untuk membina kerukunan antarperguruan silat yang ada di Kabupaten Madiun dan sekitarnya sehingga tercipta situasi dan kondisi yang kondusif.

Kegiatan-kegiatan publik lain yang dapat menjadi arena integrasi adalah kegiatan keagamaan seperti Musabaqah Tilawatil Quran (MTQ). Keterlibatan pendekar dari berbagai perguruan dalam MTQ yang diselenggarakan di Kota Madiun sebagai tuan rumah MTQ XXIV Jawa Timur pada 19-26 Juni 2011 menjadi arena integrasi. Dalam monemtum itu ditampilkan tarian silat seni yang melibatkan 800 pesilat dari dua perguruan pencak silat di Kota Madiun. Para pendekar saat itu juga dapat memfungsikan kependekarannya sebagai sosok yang menenteramkan, bukan 
menakutkan. Pemerintah Kota Madiun juga akan berupaya menjadikan ikon silat sebagai aset wisata yang dikemas dalam bentuk festival (Wawancara dengan Maidi, Sekda Kota Madiun, 22 Desember 2012).

\section{Pembahasan}

Konflik antarperguruan silat di Kabupaten Madiun dapat dirunut sejak Ki Hadjar Hardjo Oetomo berbeda pandangan dengan gurunya $\mathrm{Ki}$ Ngabehi dalam pengembangan perguruan. $\mathrm{Ki}$ Hadjar memiliki gagasan untuk menyebarkan secara lebih luas ilmu Setia Hati dan menjadi alat perjuangan melawan penjajahan. Gagasan tersebut tidak sejalan dengan doktrin perguruan yang dipegang teguh oleh Ki Ngabehi bahwa penyebaran ilmu Setia Hati tidak dapat dilakukan oleh sembarang orang dan di sembarang tempat.

Perbedaan pandangan guru-murid tersebut menimbulkan konflik tersembunyi. Ki Ngabehi sendiri tidak melarang dan tidak pula menyetujui. Ki Hadjar mendirikan perguruan sendiri yang kemudian menjadi Perguruan Setia Hati Terate. Ki Ngabehi menghormati pandangan dan langkah $\mathrm{Ki}$ Hadjar tersebut dan Ki Ngabehi pun menghormati pandangan gurunya. Demikian pula ketika R. Djimat Hendro Soewarno mendirikan Setia Hati Tunas Muda Winongo. Pihak Setia Hati Panti juga membiarkannya. Sampai tahap ini, konflik yang terjadi dapat disebut fase latensi dimana perbedaan yang ada dapat diterima. Perbedaan pandangan guru-murid tersebut mencerminkan dinamika internal perguruan yang masih dalam batas kewajaran.

Konflik mengalami eskalasi pasca Peristiwa G30S. Bentrok antara para pendekar dari dua perguruan, yaitu Perguruan Setia Hati Terate dan Setia Hati Winongo mengakibatkan hubungan kedua- nya mulai memburuk. Mereka mengerahkan berbagai sumber daya yang dimiliki. Komunikasi kedua perguruan terhambat oleh muatan-muatan emosi dan sentimen kelompok. Perbedaan-perbedaan semakin ditonjolkan meskipun keduanya berawal dari satu perguruan.

Konflik semakin meningkat dan melibatkan massa banyak sejak tahun 1990an ketika jumlah anggota baru kedua perguruan semakin banyak dari kalangan remaja usia 17 tahun. Pelanggaranpelanggaran terhadap etika perguruan mulai merebak karena tidak adanya sanksi organisatoris yang jelas. Kekerasan mudah meletus dan melibatkan massa pendukung kedua perguruan. Mereka terjebak dalam konflik yang tidak berkesudahan hingga saat ini. Konflik memasuki fase terjebak (entrapment).

Fase terjebak memerlukan tindakantindakan pengamanan oleh aparat untuk menghentikan kekerasan. Petugas keamanan dituntut netral dan memahami faktor-faktor psikologis konflik, terutama psikologi partisan konflik dari kalangan remaja dan psikologi sosial masyarakat Madiun. Program-program pemberdayaan untuk rekonsiliasi menjadi penting dan pendekatan keamanan mulai dikurangi, terutama di zona-zona aman.

Sasaran pemberdayaan untuk rekonsiliasi harus mencakup partisan tingkat elite dan menengah kedua perguruan, pihak netral seperti Setia Hati Panti dan aparat keamanan, serta pihak yang paling rawan, terutama dari kalangan anggota perguruan usia remaja. Kalangan ini perlu diperhatikan lebih serius untuk ditarik ke posisi netral ataupun mencegah mereka terlibat menjadi partisan konflik. Mereka yang telah berada di posisi netral dikembangkan menjadi kelompok inti rekonsiliasi untuk memperluas zona damai. Berbagai upaya mediasi perlu dilakukan melalui diplomasi ulang alik, 
menyelenggarakan pertemuan besar yang dihadiri oleh partisan, stakeholder partisan, dan pihak netral ataupun diselenggarakan oleh pihak ketiga yang cakap dan memahami permasalahan konflik untuk bersama-sama mencari dan menemukan cara damai penyelesaian konflik.

Karakteristik konflik menentukan cara-cara penyelesaiannya. Konflik antarperguruan silat di Madiun memiliki akar sejarah panjang yang menyangkut klaim kebenaran historis masing-masing perguruan. Kedua perguruan sama-sama mengklaim sebagai penerus ilmu Setia Hati Ki Ngabehi. Namun demikian, keduanya terpisah baik secara keilmuan maupun organisasi. Simbol-simbol dan tradisi di masing-masing perguruan menjadi persoalan krusial yang sering memicu konflik. Suran Agung, Halal bihalal, dan Pengesahan yang menjadi tradisi dan memiliki spirit yang sama sering menjadi arena konflik sosial yang terjadi secara massal.

Faktor historis tersebut mempengaruhi pembentukan identitas sosial kedua perguruan sebagai penerus ilmu Setia Hati. Meskipun berakar pada satu perguruan, namun masing-masing mengembangkan identitas sosial dengan simbolsimbol dan etika perguruan tersendiri. Simbol-simbol digunakan untuk memperkuat identitas dalam berbagai bentuknya (logo, kostum, tugu). Masyarakat Madiun dan sekitarnya seolah terpolarisasi ke dalam dua kekuatan kelompok perguruan silat tersebut.

Faktor historis juga menimbulkan berkembangnya stereotip negatif di kedua perguruan. Ingatan-ingatan kolektif di masa lalu diproduksi terus menerus sehingga menghambat komunikasi dan interaksi sosial antaranggota kedua perguruan dan sering memicu emosi dan sentimen kelompok.

Emosi dan sentimen kelompok perlu ditransformasikan menjadi hubungan baik serta terciptanya etos berdamai sehingga terbuka kemungkinan untuk memperbarui hubungan. Keesediaan dan kerelaan kdua perguruan untuk menyadari apa yang telah terjadi pada masa lalu menjadi penting agar terjadi transformasi kesadaran. Transformasi kesadaran tersebut penting untuk membangun hubungan baru yang lebih baik. Masing-masing perguruan semestinya juga bersedia merubah sudut pandangnya mengenai posisi dan identitas kelompok sendiri, posisi dan identitas kelompok lain seperti direkomendasikan Long \& Brecke (2003:30). Dengan cara begitu, upayaupaya rekonsiliasi akan menemukan jalannya.

Upaya-upaya rekonsiliasi yang dilakukan dengan pendekatan keamaan akhir-akhir ini relatif berhasil mengendalikan dan mengurangi kekerasan. Pengerahan 5.000 personil aparat keamanan mampu menjamin keamanan dari konflik kekerasan massal. Namun demikian, suasana sosiopsikologis di tingkat bawah belum banyak berubah karena pendekatan keamanan hanya diberlakukan dalam momentum-memontum tertentu yang rawan konflik.

Rekonsiliasi dengan pendekatan kultural menjadi pilihan yang lebih potensial. Festival pencak silat yang diselenggarakan setiap tahun oleh Pemerintah Kabupaten Madiun berpotensi menjadi arena integrasi. Keterlibatan pendekar dari berbagai perguruan dalam MTQ yang diselenggarakan di Kota Madiun beberapa waktu lalu juga dapat menjadi arena integrasi. Para pendekar dapat memfungsikan kependekarannya sebagai sosok yang menenteramkan bukan menakutkan. Upaya Pemerintah Kota Madiun menjadikan ikon silat sebagai aset wisata yang dikemas dalam bentuk festival juga potensial menjadi arena integrasi yang potensial bagi upaya rekonsiliasi kultural. Rekonsiliasi kultural merupakan upaya 
rekonsiliasi dengan memberdayakan simbolsimbol budaya dan sosial untuk menciptakan suasana dialogis dan harmonis melalui cara-cara proeksistensi yang terjelmakan ke dalam tindakan dan aksi-aksi nyata dalam berbagai peristiwa kehidupan.

\section{Simpulan dan Saran}

\section{Simpulan}

Konflik antarperguruan silat di Kabupaten Madiun dapat dirunut sejak Ki Hadjar Hardjo Oetomo berbeda pandangan dengan gurunya $\mathrm{Ki}$ Ngabehi dalam pengembangan Perguruan Setia Hati. Ki Hadjar Hardjo Oetomo kemudian mendirikan Perguruan Setia Hati Terate. Perbedaan pandangan guru-murid tersebut menimbulkan konflik tersembunyi. Demikian pula ketika R. Djimat Hendro Soewarno mendirikan Setia Hati Tunas Muda Winongo. Sampai tahap ini, konflik yang terjadi dapat disebut fase latensi dimana perbedaan yang ada dapat diterima. Perbedaan pandangan guru-murid tersebut mencerminkan dinamika internal perguruan yang masih dalam batas kewajaran.

Konflik mengalami eskalasi pasca Peristiwa G30S. Bentrok antara para pendekar dari dua perguruan, yaitu Perguruan Setia Hati Terate dan Setia Hati Winongo mengakibatkan hubungan keduanya mulai memburuk, meskipun kedua perguruan bukanlah partisan dalam peristiwa tersebut. Komunikasi terhambat oleh muatan-muatan emosi dan sentimen kelompok serta perbedaan-perbedaan mulai semakin ditonjolkan dan stereotip negatif mulai berkembang.

Konflik semakin meningkat dan melibatkan massa banyak sejak tahun 1990an ketika jumlah anggota baru kedua perguruan semakin banyak dari kalangan remaja usia 17 tahun. Pelanggaranpelanggaran terhadap etika perguruan mulai merebak karena tidak adanya sanksi organisatoris. Kekerasan mudah meletus dan melibatkan massa pendukung kedua perguruan. Mereka terjebak dalam konflik yang tidak berkesudahan hingga saat ini. Konflik memasuki fase terjebak (entrapment). Suran Agung, Halal bihalal, dan Pengesahan yang menjadi tradisi dan memiliki spirit yang sama sering menjadi arena konflik sosial yang terjadi secara massal.

Karakteristik konflik menentukan cara-cara penyelesaiannya. Konflik antarperguruan silat di Madiun memiliki akar sejarah panjang yang menyangkut klaim kebenaran historis masing-masing perguruan. Kedua perguruan sama-sama mengklaim sebagai penerus ilmu Setia Hati Ki Ngabehi, namun terpisah secara keilmuan dan organisasi. Simbol-simbol dan tradisi di masing-masing perguruan menjadi persoalan krusial yang sering memicu konflik. Pendekatan keamaan relatif berhasil mengendalikan dan mengurangi kekerasan. Namun demikian, suasana sosiopsikologis di lapis bawah belum banyak berubah.

Rekonsiliasi dengan pendekatan kultural menjadi penting dilakukan dan pendekatan keamanan mulai dikurangi. Arena-arena integrasi seperti Festival Pencak Seni Tradisi dapat diberdayakan sebagai media rekonsiliasi dengan pendekatan kultural. Pendekatan kultural ini terlebih dahulu dilakukan dengan transformasi kesadaran melalui upaya-upaya pemaafan terhadap masa lalu untuk memperbarui hubungan. Dari situ rekonsiliasi kultural dapat menjadi pilihan yang lebih memberi harapan. Rekonsiliasi kultural merupakan upaya rekonsiliasi dengan memberdayakan unsur-unsur budaya dan sosial untuk menciptakan suasana dialogis dan harmonis melalui cara-cara proeksistensi yang terjelmakan ke dalam tindakan dan aksi-aksi nyata dalam berbagai peristiwa kehidupan. 


\section{Saran}

Diperlukan kearifan dari pihak-pihak yang berkonflik dalam menyikapi faktorfaktor historis penyebab konflik. Sejarah memang dapat menjadi penentu kehidupan di masa kini dan mendatang, tetapi sejarah bukanlah sesuatu yang final. Sejarah dapat berubah dengan ditemukannya fakta-fakta baru dan kecanggihan intepretasi untuk kepentingan kemanusiaan.

Pendekatan keamanan masih diperlukan dalam batas-batas yang wajar, terutama pada momentum-momentum dan tempat yang selama ini potensial memicu dan menjadi arena konflik. Arena-arena integrasi perlu semakin diperbanyak dan diperluas jangkauan serta keterlibatan pihakpihak yang berkonflik. Program-program pemberdayaan untuk rekonsiliasi dengan pendekatan kultural perlu segera disiapkan dan pendekatan keamanan mulai dikurangi.

Penelitian ini perlu ditindaklanjuti dengan fokus pada model rekonsiliasi kultural untuk mengatasi konflik antarperguruan silat di Madiun. Model rekonsiliasi kultural diharapkan dapat menjadi blue print bagi semua pihak dalam mengelola konflik sosial di Madiun.

\section{Ucapan Terima Kasih}

Penulis menyampaikan terima kasih yang sebesar-besarnya kepada Ditlitbamas Direktorat Jenderal Pendidikan Tinggi Departemen Pendidikan dan Kebudayaan yang telah mendanai penelitian fundamental ini dengan Surat Perjanjian Nomor 272/SP2H/PL/ Dit.Litbamas/IV/2011. 


\section{Daftar Pustaka}

Agustino, Leo, Dasar-Dasar Kebijakan Publik, Bandung: Alfabeta, 2006.

Ali, Achmad, Sosiologi Hukum: Kajian Empiris terhadap Pengadilan, Jakarta: STIH IBLAM, 2004.

Bar-Tal, D. 2000. "From Intractable Conflict Through Conflict Resolution To Reconciliation: Psychological analysis." Political Psychology, 21, 351-365.

Blau, Peter, Exchange and Power in Social Life, Wiley, 1964.

Burton, John. 1990. Conflict: Resolution and Provention. New York: St. Martin's Press.

Chang, William, "Kesejahteraan Rakyat di Tengah Konflik", Kompas, 27 Januari 2001.

Craig Arendse, Robert Evans dan John C Nelson, Advanced Training for Mediation, PSPP UKDW, Yogyakarta, 2000.

Fanani, Ahmad Fuad, "Fajar Baru Kehidupan Bangsa", Kompas, 3 Maret 2003.

Fisher, Simon, et.al., Mengelola Konflik: Keterampilan dan Strategi untuk Bertindak, Edisi Bahasa Indonesia, Jakarta: British Council, 2001.

Haryatmoko, "Hukum dan Moral dalam Masyarakat Majemuk", Kompas, 11 Juli 2001.
Long, William J. \& Peter Brecke 2003. War and Reconciliation: Reason and Emotion in Conlict Resolution. Cambridge, MA: MIT Press.

Mamar, Sulaiman, 2002, Konflik dan Kekerasan, Makalah Disajikan Pada Temu Budaya Sulwesi Tengah Di Palu, September 2003.

M Dian Nafi', 2005, "Manajemen Konflik", Makalah, disajikan dalam Pelatihan Manajemen Konflik Lembaga Pelatihan Manajemen dan Pengembangan Masyarakat Pondok Modern Darussalam Gontor di Mantingan Ngawi, Ahad, 6 Pebruari 2005.

North, J. 1998. "The 'Ideal' of Forgiveness: A Philosopher's Exploration." In Exploring Forgiveness, ed. R. D. Enright and J. North. Madison, WI: The University of Wisconsin Press.

Parsons, Talcott, The Social System, Free Press, 1951.

Pusat Pemberdayaan Rekonsiliasi dan Perdamaian Universitas Kridawacana (PPRP Ukrida) Jakarta, Case Writing Training for Conflict Transformation, Bogor, Maret 2001.

Pusat Studi dan Pengembangan

Perdamaian UKDW Yogyakarta, Pemberdayaan untuk Rekonsiliasi, Yogyakarta: PSPP UKDW, 1998. 
125|Agastya Vol. 02 No. 01 Januari 2012

R. Djimat Hendro Soewarno, Pusaka

Pencak Silat Tiga Zaman

Persaudaraan Setia-Hati

Winongo Tunas Muda, tidak diterbitkan.

Singgih Joyohusudo dkk, Buku Peringatan

Persaudaraan Setia-Hati 19031963, tidak diterbitkan.

Suparto, Toto, "Negara dalam Spiral Kekerasan", Kompas, 16 Februari 2006. 